\title{
Knowledge, Attitudes and Practices towards Oral Health among School Teachers in Chengalpattu Taluk, Kanchipuram District Tamilnadu
}

\author{
Balaji Venugopal ${ }^{1}$, Ranjith Kannan², Buvaneshwari Parasuraman³ ${ }^{3}$ Sivakumar Nagamani ${ }^{4}$
}

\begin{abstract}
${ }^{1}$ Department of Dental Surgery, Government Villupuram Medical College and Hospital, Villupuram, Tamilnadu, India. ${ }^{2}$ Department of Public Health Dentistry, Chettinad Dental College and Research Institute, Kancheepuram, Tamilnadu, India. ${ }^{3}$ Department of Corporate Secretaryship, Avvaiyar Government College for Women, Karaikal, Puducherry, India. ${ }^{4}$ Department of Pharmacology, ASAN Memorial Dental College and Hospital, Chengalpattu, Tamilnadu, India.
\end{abstract}

\section{ABSTRACT}

\section{BACKGROUND}

Dental professionals are often invited by different school authorities to deliver lectures on oral health and to provide preventive services. The usual target population behind most endeavors comprises the, young school children, and it is with the aim of improving their oral health knowledge, that such programmes are held. However, the fact remains that any child's knowledge and practices are by and large a reflection of what he sees or is taught in his immediate surroundings. We wanted to assess the level of knowledge, attitudes and practices towards oral health among schoolteachers in Chengalpattu taluk, Kanchipuram district.

\section{METHODS}

Using simple random sampling technique, a questionnaire study was carried out among 50 government schoolteachers and 50 private schoolteachers in Chengalpattu Taluk. The questionnaire used was a closed ended, self-administered questionnaire consisting of 30 questions pertaining to Knowledge, Attitudes and Practices towards oral health

\section{RESULTS}

About $37.9 \%$ of government teachers and $36 \%$ of private teachers had knowledge regarding dental caries, $48 \%$ of government teachers and $34.9 \%$ of private teachers had knowledge regarding gum diseases and $26 \%$ of government teachers and $22.7 \%$ of private teachers had knowledge regarding malocclusion. Moreover $41 \%$ of government teachers and $32.1 \%$ of private teachers had knowledge regarding oral cancer. $83.9 \%$ schoolteachers were getting information regarding oral health through dentists or doctors. When enquired regarding practices, $63 \%$ of schoolteachers brushed their teeth twice daily.

\section{CONCLUSIONS}

Knowledge was highest among the government schoolteachers compared to private schoolteachers among Chengalpattu taluk in Kanchipuram district.

\section{KEY WORDS}

Oral Health, School Teacher, Knowledge, Attitude, Practices
Corresponding Author: Dr. Ranjith Kannan, Department of Public Health Dentistry, Chettinadu Dental College and Research Institute, Chennai, Tamilnadu, India. E-mail: drranjith84@gmail.com

DOI: $10.14260 /$ jemds/2020/92

Financial or Other Competing Interests: None.

How to Cite This Article:

Venugopal B, Kannan R, Parasuraman B, et al. Knowledge, attitudes and practices towards oral health among schoolteachers in Chengalpattu taluk, Kanchipuram district Tamilnadu. J. Evolution Med. Dent. Sci.2020;9(07):402-408,

10.14260/jemds/2020/92

Submission 12-12-2019,

Peer Review 22-01-2020,

Acceptance 28-01-2020,

Published 17-02-2020. 


\section{BACKGROUND}

Dental professionals are often invited by different school authorities to deliver lectures on oral health and to provide preventive services. The usual target population behind most endeavours comprises the, young school children, and it is with the aim of improving their oral health knowledge, that such programmes are held. However the fact remains that any child's knowledge and practices are by and large a reflection of what he sees or is taught in his immediate surroundings. ${ }^{1}$

Dentist and dental hygienists are often asked to participate in school oral health programmes at the elementary level. Schools are ideal place for preventive programmes because service can be made available to all children, including those who, for a variety of reasons, may not be receiving professional care. School teacher's resource are to conduct oral health education. According to Kenneya school administrator, "school have a tremendous capacity to be supportive of programs involving preventive health and preventive dentistry for children". Elementary schoolteachers traditionally have played a role in educating children about how to prevent oral diseases and promote oral health. Teachers typically are involved in additional activities, such as lending support for, and/or actively participating in various school- based primary prevention programs. Hence who else but the schoolteachers, who spend a considerable amount of time with the children are to be influenced in order to inculcate sound knowledge and ideal practices among the young minds. It is the teachers who are the passive recipients of the lectures delivered by the visiting dentist. It is they, who can been trusted with the role of secularly carrying out various preventive services in the long run. Health education programs in schools may be conducted by external groups such as public health agencies, dental societies, and private dentists, offices, or be provided internally by school nurses and teachers. The advantages of using school personnel are the potential for improved continuity of instruction and lowered cost of the service. Thus increasing oral health knowledge of the schoolteachers provides an opportunity to educate an important segment of the public that has an access to the large population of the young people. Teachers have the unique potential of preparing a future generation of correctly informed health care. ${ }^{2}$

The number of teachers worldwide at the primary school level has been reported to be around 23.9 million. By virtue of their opportunity to influence large numbers of children and their parents, teachers represent a significant resource in implementing the recommendation for the use of alternative personnel in the struggle against preventable diseases such as oral diseases. The use of teachers in school health education and health promotion holds many advantages including continuity in instructions being given, integration of general and oral health with other activities as well as the overall low costs associated with such programmes. In addition to the direct benefits to students, school health education and health promotion programmes which include health promotion for staff have been shown to have beneficial effects for teachers in terms of reduced teacher absenteeism and improved morale and quality of classroom instructions. The use of teachers in health education, however, carries certain disadvantages, the major one being that teachers may be insufficiently trained to deliver such messages. This lack of training on aspects of oral health has been shown to prevent teachers from participating in teaching pupils effectively. In addition, lack of resources, lack of time, and failure to incorporate oral health into the curriculum has been implicated as barriers to teaching oral health education in schools. ${ }^{3}$

Lack of teacher training may be a significant barrier to the success of health-promoting school programmes and may in fact have resultant unfavorable repercussions on the pupils' health. Several international studies have been conducted to investigate elementary schoolteachers' oral health knowledge, attitude and willingness to participate in dental health programmes. Evidence from the majority of developing countries where these studies have been conducted have shown that teachers, though deficient in their knowledge of oral health, have still shown interest in providing oral health education to their pupils. These studies also indicate that while the majority of the teachers were interested in participating in dental health education, they were less motivated to participate in those activities which involved the use of school time and which required their direct supervision. Other studies have shown that some teachers, though quite knowledgeable with respect to oral health, had poor levels of motivation and behaviour related to oral health. ${ }^{4}$

The role of education, particularly the early education is imperative, since it is easier to shape the behaviour of individuals when they are relatively at a young age. Children spend almost up to seven hours at education facilities where they are constantly learning, even outside classrooms. They easily pick up knowledge, habits and skills. Therefore educators, schoolteachers in specific have the ability to not only shape but also change certain attitudes among their pupils along with the collaborated effort of the parents. Teachers by teaching about oral health care will not only be improving and promoting for oral heath, but preventing the oral health problems as well. The important role of teachers in oral health education cannot be ignored, but most teachers are not $t$ rained for this task and they have low abilities and willingness for it. Oral health education sessions conducted by teachers at school were observed to be deficient in content and in methods. Teachers' knowledge about oral health and current methods of prevention is incomplete, and inaccurate in some instances. Several studies have shown that most teachers have positive attitude towards oral health.

Teachers with sound knowledge and positive attitude about oral health care and practices will be motive in promoting and maintaining the oral health care of school going children. Hence this study was designed to assess the knowledge, attitude and practice towards oral health among schoolteachers in Chengalpattu Taluk of Kanchipuram district. $^{5}$

\section{METHODS}

After obtaining ethical clearance from the Institutional Review Board of Meenakshi Academy of Higher Education and 
Research, Chennai, this cross-sectional survey was carried out to evaluate the level of knowledge, attitudes and practices towards oral health among schoolteachers in Chengalpattu taluk of Kanchipuram district. The source of data was primary and was obtained through as a questionnaire survey. The survey was conducted among Government and private schoolteachers who were employed in a schools of Chengalpattu taluk. Schoolteachers employed in the schools of Chengalpattu taluk were included in the study. Teachers who are not willing to participate and teachers who were absent on the days of examination were excluded from the study.

\section{Obtaining Approval from the Authorities}

The nature and purpose of the study was explained to the heads of the schools (Correspondent, Principal, Headmaster/ Headmistress, etc.) and prior permission was obtained to conduct the study in their schools.

\section{Pilot Study}

A pilot study was carried out to pre-test the questionnaire and check the feasibility of the study. A total of 50 government and 50 private schoolteachers participated in the pilot study. Following the pilot study necessary corrections were done and the revised questionnaire was prepared for the survey.

\section{Sample Size}

Following the pilot study, the required sample size was calculated using the formula:

$$
n=\frac{\left(Z_{\alpha}+Z_{\beta}\right)^{2}\left(P_{1} Q_{1}+P_{2} Q_{2}\right)}{\left(P_{1}-P_{2}\right)^{2}}
$$

Where $\mathrm{n}$ - is the required sample size per group, $\mathrm{Z}_{\alpha}-\mathrm{Z}$ value for $\alpha \%$ level of significance (Normally $5 \%$ ), $Z_{\beta}-Z$ value for $(1-\beta)$ $\%$ of power, $\mathrm{P}_{1}$ - Proportion in Group 1 (\% based on knowledge correct responses among government teacher), $\mathrm{Q}_{1}=1-\mathrm{P}_{1}, \mathrm{P}_{2}-$ Proportion in Group 2 (\% based on knowledge correct responses among private teacher), $\mathrm{Q}_{2}=1-\mathrm{P}_{2}$. Here, $\mathrm{P}_{1}=64.0$, $\mathrm{P}_{2}=56.0, \mathrm{Q}_{1}=36.0, \mathrm{Q}_{2}=44.0, \mathrm{Z}_{\alpha}=1.96$ for $5 \%$ of level of significance, $Z_{\beta}=1.282$ for $90 \%$ of power. By applying the above formula the required sample size per group was 389 . Based on the knowledge with power of the study set at $90 \%$, as the maximum sample size 400 government and 400 private schoolteachers were assigned for the study.

\section{Sampling Methodology}

Simple Random Sampling methodology was used for the present study. There were 16 government and18 private schools in Chengalpattu taluk. The schools were randomly selected one after the other to reach the required sample size. All the teachers who were employed in the selected government and private schoolteachers formed the study population. In this study 13 government and8 private schools were randomly selected to reach the required sample size population.

\section{Collection of Data}

Data was collected by using self-administered closed ended questionnaire. The questionnaire was developed in English language. Each questionnaire contained two parts: the first part with general information of the participants and the second part dealt with the questions regarding knowledge, attitude and practices towards oral health. The questionnaire consisted of 30 questions. The knowledge questions were divided as given in the flowchart. 5 questions on attitudes and 5 questions on oral hygiene practices. The pre-tested selfadministered questionnaires were given to all study subjects at their place of work. The questionnaire was explained in order to avoid any ambiguity. They were assured of the confidentiality of their responses and were requested to give appropriate answers. The filled questionnaires were collected on the same day.

\begin{tabular}{|c|c|c|c|}
\hline $\begin{array}{l}\text { Government } \\
\text { Schools }\end{array}$ & 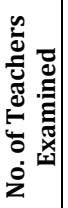 & Private Schools & 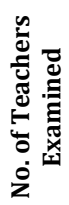 \\
\hline \begin{tabular}{|c|} 
Govt. Higher Secondary School \\
Chengalpattu \\
Aringhar Anna Municipal High School, \\
MPL Primary School Anumanthaputheri \\
MPL Primary School Vedappar St \\
Chengalpattu \\
MPL High School church road \\
Chengalpattu \\
MPL Primary School Mettu St \\
Chengalpattu \\
MPL high School Mariammankoil St \\
Chengalpattu \\
MPL High School Mettu St Chengalpattu \\
MPL Primary School Vallampost \\
Chengalpattu \\
Govt. middle School Kathan St \\
Chengalpattu \\
MPL High School Vadamalli St \\
Chengalpattu \\
MPL High School \\
Big Nathamst Chengalpattu
\end{tabular} & $\begin{array}{l}48 \\
52 \\
23 \\
19 \\
46 \\
21\end{array}$ & \begin{tabular}{|c} 
Alison Kasi Higher Secondary \\
School \\
Little Jacky Matriculation \\
Higher Secondary School \\
RKM Boys Higher Secondary \\
School \\
St. Joseph Higher Secondary \\
School \\
RKM Girls Higher Secondary \\
School \\
SDA Higher Secondary School \\
RKM Primary School \\
Progress M S
\end{tabular} & $\begin{array}{l}64 \\
53 \\
61 \\
58 \\
\\
62 \\
52 \\
52 \\
28 \\
28\end{array}$ \\
\hline $13 \mathrm{G}$ & 400 & 8 Private Schools & 400 \\
\hline
\end{tabular}

\section{Statistical Analysis}

The resulting data was coded, and statistical analysis was done using SPSS (Statistical Package for Social Sciences) version 17.0 software. In the present study, frequency and percentage were calculated, along with mean and standard deviation; $\mathrm{p}$ value was fixed at $<0.05$. A comparison between the level of knowledge among government and private schoolteachers was done using Chi-square test.

\section{RESULTS}

\section{Demographic Features (Table 2)}

The total study population was 800 schoolteachers, of which 343 (42.9\%) were $\leq 30$ years aged and 457 (57.1\%) members were $\geq 30$ years. Mean average of age study subjects are 41.16 with $260(32.5 \%)$ being males and 540 (67.5\%) being females. 486 (60.8\%) participants had 1-5 years of teaching experience, 157 (19.6\%) of the participants had 6-10 years of teaching experience and 157 (19.6\%) participants had above 11 years of teaching experience. $238(29.8 \%)$ participants were diploma holders, and 347 (43.4\%) participants were under graduates and 215 (26.9\%) participants were postgraduates. $4(0.5 \%)$ participants had of monthly income less than 10000. 295 (36.9\%) participants had monthly 
income 10001-15000 and 501 (62.6\%) participants had monthly income above 15001. (Table 2).i

\section{Knowledge Regarding Dental Caries (Table 3)}

Among the study subjects, $43.2 \%$ said that the tooth decay was infectious, $56.8 \%$ said that the tooth decay was not infectious. The differences found was statistically significant $(p<0.05)$. $45.9 \%$ responded that the brushing regularly will prevent dental decay. $1.4 \%$ said that the rinsing after every meal will prevent dental decay. $52.8 \%$ of them responded that avoiding sweets and sticky foods, brushing regularly, rinsing after every meal will prevent dental decay. The differences noted was statistically significant $(\mathrm{p}<0.05) .22 .1 \%$ of the study subjects said that the eating fibrous food is a method of preventing dental caries. $72.5 \%$ said that eating fibrous food is not a method of preventing dental caries. 5.4\% said that they don't know the eating fibrous food is a method of preventing dental caries. The differences found was statistically significant ( $p<0.05$ ). 33.4\% said that the using sealant on the teeth will prevent dental caries. $48.1 \%$ said that the using sealant on the teeth will not prevent dental caries. 18.5\% said that they don't know the using sealant on the teeth will prevent dental caries. The differences found was statistically significant $(p<0.05)$. $65.1 \%$ of the study subjects said that the using fluoride toothpaste helps to repair early carious lesions. $21.1 \%$ said that the using fluoride toothpaste was not help to repair early carious lesions. $13.8 \%$ said that they don't know if using fluoride toothpaste helps to repair early carious lesions in teeth. The differences found was not statistically significant $(p>0.05)$.

\section{Knowledge Regarding Gum Diseases (Table 4)}

Result revealed that $20.6 \%$ of the study subjects said that the tobacco chewing was considered to be an important factor in the causation of gum diseases $74 \%$ said that the tobacco chewing was not considered to be an important factor in the causation of gum diseases. 5.4\% said that they didn't know that tobacco chewing was considered to be an important factor in the causation of gum diseases. The differences found was not statistically significant ( $\mathrm{p}>0.05$ ). $40 \%$ said that the rinsing their mouth after food was believed to be a significant factor in the prevention of gum diseases. $60 \%$ said that rinsing their mouth after food was believed to be not a significant factor for the prevention of gum disease. The differences found was statistically significant $(\mathrm{p}<0.05)$. Result revealed that the $51 \%$ said that the gum disease can be progressive, leading to loss of bone that supports the teeth. $42 \%$ said that gum disease cannot be progressive, leading to loss of bone that supports the teeth. 7\% said that they don't know if gum disease can be progressive, leading to loss of bone that supports the teeth. The differences found was statistically significant $(\mathrm{p}<0.05)$. $59 \%$ said that bleeding on brushing was an early sign of gum disease. $31 \%$ said that bleeding on brushing is not an early sign of gum disease. $10 \%$ said that they didn't know if bleeding on brushing was an early sign of gum disease. The differences found was highly statistically significant $(p<0.05) .60 \%$ said that the regular and proper tooth brushing would protect them from gum diseases. $21 \%$ said that the using soft food would protect from gum diseases. 19\% said that they did not know which would protect from gum diseases. The differences found was not statistically significant $(\mathrm{p}>0.05)$.

\begin{tabular}{|c|c|c|c|}
\hline \multicolumn{2}{|c|}{ Variables } & N & $\mathbf{\%}$ \\
\hline \multirow{2}{*}{ Age group } & $\leq 30$ yrs. & 343 & 42.9 \\
\cline { 2 - 4 } & $>30$ yrs. & 457 & 57.1 \\
\hline \multirow{2}{*}{ Gender } & Male & 260 & 32.5 \\
\cline { 2 - 4 } & Female & 540 & 67.5 \\
\hline \multirow{3}{*}{ Years of Experience } & $\leq 5$ yrs. & 486 & 60.8 \\
\cline { 2 - 4 } & $6-10$ yrs. & 157 & 19.6 \\
\cline { 2 - 4 } & $>10$ yrs. & 157 & 19.6 \\
\hline \multirow{2}{*}{ Educational } & Diploma & 238 & 29.8 \\
\cline { 2 - 4 } Qualification & UG & 347 & 43.4 \\
\cline { 2 - 4 } & PG & 215 & 26.9 \\
\hline \multirow{3}{*}{ Income } & $<$ Rs 10000 & 4 & .5 \\
\cline { 2 - 4 } & Rs 10001 - 15000 & 295 & 36.9 \\
\cline { 2 - 4 } & $>$ Rs 15000 & 501 & 62.6 \\
\cline { 2 - 4 } & Total & $\mathbf{8 0 0}$ & $\mathbf{1 0 0 . 0}$ \\
\hline
\end{tabular}

Table 2. Demographic Details of School Teachers Based on Age, Gender, Years of Experience, Education, and Income

\begin{tabular}{|c|c|c|c|}
\hline $\begin{array}{l}\text { Sl. } \\
\text { No. }\end{array}$ & Questions & School Teachers N (\%) & $\begin{array}{c}\text { p- } \\
\text { Value }\end{array}$ \\
\hline 1 & $\begin{array}{c}\text { Is tooth decay infectious } \\
\text { Yes } \\
\text { No } \\
\text { Don't know }\end{array}$ & $\begin{array}{c}346(43.2 \%) \\
454(56.8 \%) \\
0\end{array}$ & 0.045 \\
\hline 2 & $\begin{array}{c}\text { How can you prevent dental decay? } \\
\text { Avoid sweets and sticky foods } \\
\text { Brushing regularly } \\
\text { Rinsing after every meal } \\
\text { All of the above }\end{array}$ & $\begin{array}{c}0 \% \\
367(45.9 \%) \\
11(1.4 \%) \\
422(52.8 \%) \\
\end{array}$ & 0.021 \\
\hline 3 & $\begin{array}{c}\text { Eating fibrous food is a method of } \\
\text { preventing dental caries } \\
\text { Yes } \\
\text { No } \\
\text { Don't know }\end{array}$ & $\begin{array}{c}177(22.1 \%) \\
580(72.5 \%) \\
43(5.4 \%)\end{array}$ & 0.03 \\
\hline 4 & $\begin{array}{c}\text { Using sealant on the teeth will prevent } \\
\text { dental caries } \\
\text { Yes } \\
\text { No } \\
\text { Don't know }\end{array}$ & $\begin{array}{l}267(33.4 \%) \\
385(48.1 \%) \\
148(18.5 \%)\end{array}$ & 0.04 \\
\hline 5 & $\begin{array}{c}\text { Using fluoride toothpaste helps to } \\
\text { repair early carious lesions in teeth. } \\
\text { Yes } \\
\text { No } \\
\text { Don't know }\end{array}$ & $\begin{array}{l}521(65.1 \%) \\
169(21.1 \%) \\
110(13.8 \%)\end{array}$ & 0.006 \\
\hline & $\begin{array}{r}\text { ble 3. Distribution of School Te } \\
\text { Responses Regardin }\end{array}$ & $\begin{array}{l}\text { Based on Kn } \\
\text { l Caries }\end{array}$ & \\
\hline
\end{tabular}

\begin{tabular}{|c|c|c|c|}
\hline $\begin{array}{l}\text { Sl. } \\
\text { No. }\end{array}$ & Questions & $\begin{array}{c}\text { School Teachers N } \\
(\%)\end{array}$ & $\begin{array}{c}\text { p- } \\
\text { Value }\end{array}$ \\
\hline 6 & \begin{tabular}{|} 
Tobacco chewing is considered to be an \\
important factor in the causation of gum \\
diseases \\
Yes \\
No \\
Don't know \\
\end{tabular} & $\begin{array}{c}160(20.6 \%) \\
595(74 \%) \\
45(5.4 \%)\end{array}$ & 0.065 \\
\hline 7 & $\begin{array}{c}\text { Rinsing your mouth after food was } \\
\text { believed to be a significant factor in the } \\
\text { prevention of gum diseases } \\
\text { Yes } \\
\text { No } \\
\text { Don't know }\end{array}$ & $\begin{array}{l}318(40 \%) \\
482(60 \%)\end{array}$ & 0.011 \\
\hline 8 & $\begin{array}{c}\text { Gum disease can be progressive, leading } \\
\text { to loss of bone that supports the teeth. } \\
\text { Yes } \\
\text { No } \\
\text { Don't know } \\
\end{array}$ & $\begin{array}{c}405(51 \%) \\
331(42 \%) \\
64(7 \%)\end{array}$ & 0.01 \\
\hline 9 & $\begin{array}{c}\text { Bleeding on brushing is an early sign of } \\
\text { gum disease. } \\
\text { Yes } \\
\text { No } \\
\text { Don't know }\end{array}$ & $\begin{array}{c}473(59 \%) \\
312(31 \%) \\
15(10 \%)\end{array}$ & 0.002 \\
\hline 10 & $\begin{array}{c}\text { How do you protect yourself from gum } \\
\text { disease? } \\
\text { Regular and proper tooth brushing } \\
\text { Using soft food } \\
\text { Using vitamin A } \\
\text { I do not know }\end{array}$ & $\begin{array}{c}456(60 \%) \\
300(21 \%) \\
(0 \%) \\
44(19 \%)\end{array}$ & 0.76 \\
\hline \multicolumn{4}{|c|}{$\begin{array}{c}\text { Table 4. Distribution of School Teachers Based on Knowledge } \\
\text { Responses Regarding Gum Diseases }\end{array}$} \\
\hline
\end{tabular}

\section{Knowledge Regarding Malocclusion (Table 5)}

$45.5 \%$ said that the thumb sucking is considered to be an important factor in the development of protruded teeth. $49.3 \%$ said that thumb sucking is not considered to be an important factor in the development of protruded teeth. 5.3\% said that they don't know if thumb sucking is considered to be 
an important factor in the development of protruded teeth. The differences found was not statistically significant ( $P>0.05$ ). 32.5\% said that tongue thrusting is considered to be a cause for protruded teeth. $50.2 \%$ said that tongue thrusting is not considered to be a cause for protruded teeth. $17.3 \%$ said that they don't know if tongue thrusting is considered to be a cause for protruded teeth. The differences found was not statistically significant $(P>0.05) .18 .6 \%$ said that the habit of thumb sucking js normal up to $1-2$ years. $65.6 \%$ said that the habit of thumb sucking is normal up to $3-4$ years. $15.8 \%$ said that the habit of thumb sucking is normal up to 5-6 years. The differences found was statistically highly significant $(\mathrm{p}<0.01)$. $35.8 \%$ said that the premature loss of primary teeth can cause drifting of the adjacent teeth into the space. $46.4 \%$ said that the premature loss of primary teeth cannot cause drifting of the adjacent teeth into the space. $17.8 \%$ said that they did not know if premature loss of primary teeth can cause drifting of the adjacent teeth into the space. The differences found was statistically significant $(\mathrm{p}<0.05) .29 .4 \%$ said that using of the space maintainers during early loss of primary tooth will prevent malalignment of eruption impermanent teeth. 70.6 \%said that the using of the space maintainers during early loss of primary tooth will not prevents malalignment of eruption impermanent teeth. The differences found was statistically not significant $(\mathrm{p}<0.05)$.

\begin{tabular}{|c|c|c|c|}
\hline \begin{tabular}{c|c} 
Sl. \\
No.
\end{tabular} & Questions & $\begin{array}{c}\text { School Teachers } \\
\text { N (\%) }\end{array}$ & $\begin{array}{c}\text { p- } \\
\text { Value }\end{array}$ \\
\hline 11 & $\begin{array}{c}\text { Thumb sucking is considered to be an important } \\
\text { factor in the development of protruded teeth } \\
\text { Yes } \\
\text { No } \\
\text { Don't know }\end{array}$ & $\begin{array}{c}364(45.5 \%) \\
394(49.3 \%) \\
42(5.3 \%)\end{array}$ & 0.056 \\
\hline 12 & $\begin{array}{c}\text { Tongue thrusting was considered to be a cause } \\
\text { for protruded teeth } \\
\text { Yes } \\
\text { No } \\
\text { Don't know }\end{array}$ & $\begin{array}{l}260(32.5 \%) \\
402(50.2 \%) \\
138(17.3 \%)\end{array}$ & 0.34 \\
\hline 13 & $\begin{array}{l}\text { Habit of thumb sucking is considered to be } \\
\text { normal up to the ages of } \\
1-2 \text { years } \\
3-4 \text { years } \\
5-6 \text { years } \\
7-8 \text { years }\end{array}$ & $\begin{array}{l}149(18.6 \%) \\
525(65.6 \%) \\
126(15.8 \%)\end{array}$ & 0.004 \\
\hline 14 & $\begin{array}{c}\text { Premature loss of primary teeth can cause } \\
\text { drifting of the adjacent teeth into the space } \\
\text { Yes } \\
\text { No } \\
\text { Don't know }\end{array}$ & $\begin{array}{l}286(35.8 \%) \\
371(46.4 \%) \\
143(17.8 \%)\end{array}$ & 0.04 \\
\hline 15 & $\begin{array}{l}\text { Use of space maintainers during early loss of } \\
\text { primary tooth prevents malalignment of } \\
\text { eruption impermanent teeth } \\
\text { Yes } \\
\text { No } \\
\text { Don't know }\end{array}$ & $\begin{array}{l}235(29.4 \%) \\
565(70.6 \%)\end{array}$ & 0.55 \\
\hline \multicolumn{4}{|c|}{$\begin{array}{c}\text { Table 5. Distribution of School Teachers Based on Knowledge } \\
\text { Responses Regarding Malocclusion }\end{array}$} \\
\hline
\end{tabular}

\section{DISCUSSION}

Schools, with their special characters amongst other behavior affecting institutes, provide a big opportunity for promoting school children's health. School environment, curriculum, and extracurricular activity could all be utilized for promoting student's oral health and general health as well. School teachers, with their educational experience and contact with students, can actively contribute to student's health promotion, provided that they receive enough training and support to do so. School teachers have the unique potential of preparing the future generation of correctly informed health care consumers and decision makers. The current study is an attempt to tap the knowledge attitude and practices of the schoolteachers about the oral health.

The present study, majority $41 \%$ of the schoolteachers had level of knowledge about oral health. A study conducted by Ramen Haloi et al (2012) among schoolteachers in Mathura City showed that $67.9 \%$ schoolteachers had knowledge on oral health. This finding was high when compared to present study $44 \%$ of government teachers and $36.7 \%$ of private teachers had knowledge on oral health. Study was conducted by Amit Vanka et al (2012) among teachers in Bhopal, Central India showed that $61.9 \%$ of government teachers and $44.5 \%$ of private schoolteachers had knowledge on oral health. This findings was higher when compared to present study. When compared to gender $47.1 \%$ female teachers had better knowledge than $41.2 \%$ male teachers. A study conducted by Pradeep et al (2011) among primary schoolteachers in Belgaum city showed that $43 \%$ of female teachers and $23 \%$ of male teachers had knowledge on oral health. This findings was less when compared to present study.

Among the study subjects, $47.6 \%$ of government teachers and $38.8 \%$ of private teachers responded that tooth decay is infectious. The differences found were not statistically significant. A study was conducted by Pradeep et al (2011) among government primary schoolteachers in Belgaum city showed that $73.3 \%$ responded that tooth decay is not infectious. This findings were higher when compared to our present study. $54.4 \%$ of government teachers and $51.2 \%$ of private teachers responded that avoiding sweets and sticky foods, brushing regularly, rinsing after every meal will prevent dental decay. The differences found were statistically not significant. A similar study was conducted by Amit Vanka et al (2012) among schoolteachers in Bhopal which showed that avoiding sweets and sticky foods, brushing regularly, rinsing after every meal will prevent dental decay was being $46.5 \%$ and $42.8 \%$ respectively.

Moreover $22.8 \%$ of government teachers and $21.5 \%$ of private teachers responded that the eating fibrous food is a method of preventing dental caries. The differences found were statistically highly significant. A study conducted by Ramroop et al (2011) among schoolteachers in Trinidad showed that the eating fibrous food is a method of preventing dental caries was to be $35 \%$ and $38 \%$ respectively. These findings was higher when compared to present study this differences might be not aware of dietary foods. $27.6 \%$ of government teachers and $39.3 \%$ of private teachers responded correctly that using sealant on the teeth will prevent dental caries the differences found were statistically significant. A study was conducted by Mazar Salah et al (2012) among basic schoolteachers in Sudan showed that $16.3 \%$ government teachers said that the using sealant on the teeth will prevent dental caries. This findings was less when compared to the present study difference might be not aware to the recent advances in dentistry.

Result revealed that $22.8 \%$ of government teachers and $19.3 \%$ of private teachers said that the using fluoride toothpaste helps to repair early carious lesions in teeth. It was higher when compared to study conducted by Mazar Salah et al (2012) among basic schoolteachers in Sudan and Ramroop et al (2011) among schoolteachers in Trinidad showed that the used fluoride toothpaste helps to repair early carious lesions in teeth was being $45.1 \%$ and $34 \%$ respectively. $22.8 \%$ of 
government teachers and $17.3 \%$ of private teachers responded that tobacco chewing was considered to be an important factor in the causation of gum diseases the differences found were statistically highly significant. A study was conducted by Raj et al (2011) among the schoolteachers in Dharwad city showed that factor in the causation of gum diseases was $55 \%$ and $46 \%$ respectively it was higher when compared to present study. Result revealed that $45.4 \%$ of government teachers and $34.8 \%$ of private teachers said that the rinsing their mouth after food was believed to be a significant factor in the prevention of gum diseases. A study was conducted by Raj et al (2011) among the schoolteachers in Dharwad city showed that $90 \%$ government teachers and $77 \%$ private teachers the rinsing their mouth after food was believed to be a significant factor in the prevention of gum diseases. This findings was higher when compared to present study.

Result revealed that the $51.9 \%$ of government teachers and $49.3 \%$ of private teachers responded that gum disease can be progressive, leading to loss of bone that supports the teeth. A study was conducted by Benly George et al (2010) among schoolteachers in Chennai showed that $87 \%$ schoolteachers agreed that the gum disease can be progressive, leading to loss of bone that supports the teeth. These findings was high when compared to present study. $51.9 \%$ of government teachers and $39 \%$ of private teachers said that the thumb sucking was considered to be an important factor in the development of protruded teeth. The differences found were statistically significant $(\mathrm{p}<0.05)$. A study was conducted by Raj et al (2011) among the schoolteachers in Dharwad city showed that $66 \%$ and $44 \%$ said that the thumb sucking was considered to be an important factor in the development of protruded teeth. $37.1 \%$ of government teachers and $28 \%$ of private teachers said that tongue thrusting was considered to be a cause for protruded teeth the differences found were not statistically significant $(\mathrm{p}<0.05)$. A study was conducted by Raj et al (2011) among the schoolteachers in Dharwad city which showed that tongue thrusting was considered to be a cause for protruded teeth was being $50.2 \%$ and $47 \%$ respectively.

$67.7 \%$ of government teachers and $63.5 \%$ of private teachers responded correctly that thumb sucking habit normal aged between 3 to 4 years. The differences found were statistically significant. A study was conducted by Raj et al (2011) among the schoolteachers in Dharwad city which showed that. $85 \%$ and $66 \% .41 .4 \%$ of government teachers and $30.5 \%$ of private teachers said that the premature loss of primary teeth can cause drifting of the adjacent teeth into the space. A study was conducted by Raj et al (2011) among the schoolteachers in Dharwad city showed that $77.8 \%$ teachers agreed that the premature loss of primary teeth can cause drifting of the adjacent teeth into the space. The differences found was high when compared to present study. $68.7 \%$ of government teachers and $71.8 \%$ of private teachers said that the tobacco smoking is a cause for oral cancer the differences found were statistically highly significant. A study was conducted by Raj et al (2011) among the schoolteachers in Dharwad city showed that $77.6 \%$ and $88 \%$ said that the tobacco smoking is a cause for oral cancer.

$52.1 \%$ of government teachers and $26 \%$ of private teachers said that the smokeless tobacco was related to oral cancer. A study was conducted by Raj et al (2011) among the schoolteachers in Dharwad city showed that the smokeless tobacco was related to oral cancer was being $87 \%$ and $65 \%$ respectively. The differences found was high when compared to present study. $65.4 \%$ of government teachers and $53.5 \%$ of private teachers said that the consumption of alcohol will result in oral cancer it was less compare to study was conducted by Raj et al (2011) among the schoolteachers in Dharwad city showed that $53.8 \%$ government teachers and $45 \%$ private teachers responded that consumption of alcohol will result in oral cancer.

$30.6 \%$ of government teachers and $15.3 \%$ of private teachers said that the spicy food was associated with the development of oral cancer. A study was conducted by Raj et al (2011) among the schoolteachers in Dharwad city showed that the spicy food was associated with the development of oral cancer was being $36.1 \%$ and $43 \%$ respectively. The differences found were high when compared to present study in the present study, they exhibited a lack of knowledge regarding the oral health. The utilization of dental services is quite poor in this area and preventive services like sealants and topical fluorides.

\section{Attitudes Based on Oral Health}

Among the study subjects $65.4 \%$ said that they visited a dentist on when had a toothache. A study was conducted by Ramen Haloi et al (2012) among schoolteachers in Mathura city showed that $59.8 \%$ said that they visited a dentist. Results revealed that $46 \%$ said that visited a dentist regularly every 6 to 12 months. A study was conducted by Benly George et al (2010) among schoolteachers in Chennai showed that 31.5\% said that visited a dentist regularly every 6 to 12 months it was less compared to present study. 69.8\% said that dentist/ doctor is the best to motivate people towards their oral health. $17.8 \%$ said that Internet/TV/Radio is the best to motivate people towards their oral health. $12.2 \%$ said that Newspapers/books/ magazines is the best to motivate people towards their oral health. A study was conducted by Suresh Kumar et al (2010)among elementary schoolteachers in Andhra Pradesh showed that 55.5\% said that dentist/ doctor is the best to motivate people towards their oral health. $31.8 \%$ said that Internet/TV/Radio is the best to motivate people towards their oral health. $12.7 \%$ said that Newspapers/books/ magazines is the best to motivate people towards their oral health. $40.1 \%$ said that oral health was important as general health. A study conducted by Ramroop et al (2011) among schoolteachers in Trinidad showed that $29.9 \%$ said that oral health was important as general health it was low when compared to present study. $32.9 \%$ said that it is necessary to treat decay in primary teeth. A study was conducted by Ramroop et al (2011) among schoolteachers in Trinidad showed that $44 \%$ said that necessary to treat decay in primary teeth it was high compared to present study.

\section{Oral Hygiene Practices Based on Oral Health}

$23 \%$ schoolteachers said that the methods of cleaning their teeth by Horizontal and vertical technique. A study was conducted by Suresh Kumar et al (2012) among elementary schoolteachers in Andhra Pradesh which showed that 63\% revealed that the method of cleaning their teeth was by Horizontal and vertical technique. It was high when compared to present study. $31.4 \%$ said that frequency of brushing their 
teeth was twice daily. A study was conducted by Suresh Kumar et al (2012) among elementary schoolteachers in Andhra Pradesh which showed $21.3 \%$ of the study population said that frequency of brushing their teeth was twice daily, it was low when compared to present study. $100 \%$ said that toothbrush and toothpaste is the materials used for cleaning their teeth. A study conducted by Suresh Kumar et al (2010) among elementary schoolteachers in Andhra Pradesh showed that $91 \%$ of the study population toothbrush and toothpaste for cleaning their teeth and it was less compared to present study. $48.4 \%$ said that the tooth pick were used for cleaning between the teeth. A study was conducted by Pradeep et al (2011) among primary schoolteachers in Belgaum city which showed that $24.7 \%$ said that Toothpick were used for cleaning between the teeth. $43.3 \%$ school teacher's frequency of eating sweet/chocolates/pastries occasionally. A study was conducted by Pradeep et al (2011) among primary schoolteachers in Belgaum city which showed that $38.3 \%$ of the study population eat sweet/chocolates/pastries occasionally it was less when compared to present study.

\section{CONCLUSIONS}

More than $50 \%$ of schoolteachers in the present study had inadequate knowledge regarding oral disease and its prevention. Knowledge was more among government schoolteachers compared to private school teachers. Knowledge was more among female schoolteachers compared to male schoolteachers. Majority of the teachers were getting their source of information through dentist. Most of the teachers were brushing their teeth only once daily.

Recommendations

Proper training and practical support should be provided along with educational materials regarding on oral health. Schools should organize seminars, and workshops for the teachers regarding oral health. School teachers should be made cornerstones in conducting community school dental health program $6,7,8$.

\section{REFERENCES}

[1] Mudathir MS, Awooda EM. Basic schoolteachers' knowledge and attitude about tooth decay and practice towards oral health education at Khartoum province. Sudan J Med Sci 2013;8 (2):86-92.

[2] Vanka A, Yadav NS, Saxena V, et al. Oral health acquaintance, approach and practices among schoolteachers in Bhopal, Central India. J Orofac Res 2012;2 (1):15-19.

[3] Haloi R, Ingle NA, Kaur N. Caries status of children and oral health behavior, knowledge and attitude of their mothers and schoolteachers in Mathura City. J Contemp Dent 2012;2 (3):78-83.

[4] George B, John J, Saravanan S, et al. Oral health knowledge, attitude and practices of schoolteachers in Chennai. JIAPHD 2010;8 (15):85-90.

[5] Raj SM, Prasad KVV, Javali SB. Factors affecting the knowledge on prevention of oral diseases among schoolteachers of Dharwad city: a survey from India. Webmed Central Dent 2011;2 (2):4-13.

[6] Loupe MJ, Frazier PJ. Knowledge and attitudes of schoolteachers toward oral health programs and preventive dentistry. J Am Dent Assoc 1983;107 (2):22934.

[7] Lang P, Woolfolk MW, Faja BW. Oral health knowledge and attitudes of elementary schoolteachers in Michigan. Journal of Public Health Dentistry 1989;49 (1):44-50.

[8] Almas K, Al-Malik TM, Al-Shehri MA, et al. The knowledge and practices of oral hygiene methods and attendance pattern among schoolteachers in Riyadh, Saudi Arabia. Saudi Med J 2003;24 (10):1087-91. 